\title{
Intra-annual stem size variations converge across marginal populations of European beech
}

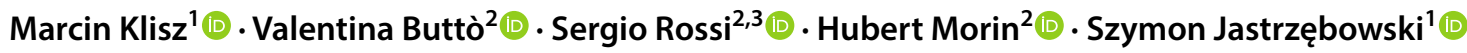

Received: 27 May 2019 / Accepted: 24 September 2019 / Published online: 1 October 2019

(c) The Author(s) 2019

\begin{abstract}
Key message The intra-annual variability in stem size of marginal beech population from south-eastern distribution range of beech in Poland is higher within than between populations.

Abstract One of the key issues of the distribution of tree species is their ability to track environmental changes. European beech (Fagus sylvatica L.) is a species highly sensitive to extreme climatic events, because of its high phenotypic plasticity. In this study, we aim to determine the variability in stem size between and within marginal beech populations. Marginal populations of beech growing under uniform environmental conditions of provenance trial offer unique opportunity to detect adaptive differentiations driven by natural selection. In this work, we studied stem size variation recorded by automatic band dendrometers in four beech marginal populations growing in a common garden in the south-eastern distribution range of beech in Poland over the period 2016-2018. Strong climatic effects and weak provenance differences in seasonal stem size variation were observed. The provenances exhibited similar climate-related seasonal stem circumference variation. A high within-provenance variation was confirmed. Temperature of spring as well as temperature and precipitation of autumn were detected as key climatic parameters mostly for onset and end of stem size variation. Maximum stem size was mostly affected by the later end of its variation, which positively affected its duration. Climatic distance between beech provenances and provenance trial had a negligible effect on the variability in seasonal stem size variation between provenances. The evidence of weak inter-provenance and high intra-provenance variation in stem size changes observed in the south-eastern distribution range indicates that an individual-based approach could be a suitable strategy, when selecting for phenotypic plasticity.
\end{abstract}

Keywords European beech $\cdot$ Stem circumference variation $\cdot$ Dendrometers $\cdot$ Marginality $\cdot$ Provenance trial

Communicated by E. Liang.

Electronic supplementary material The online version of this article (https://doi.org/10.1007/s00468-019-01915-5) contains supplementary material, which is available to authorized users.

Marcin Klisz

m.klisz@ibles.waw.pl

1 Department of Silviculture and Genetics of Forest Trees, Forest Research Institute, Raszyn, Poland

2 Département des Sciences Fondamentales, Université du Quebec à Chicoutimi, Chicoutimi, Canada

3 Key Laboratory of Vegetation Restoration and Management of Degraded Ecosystems, Guangdong Provincial Key Laboratory of Applied Botany, South China Botanical Garden, Chinese Academy of Sciences, Guangzhou, China

\section{Introduction}

Marginal populations occur at the limit of the ecological tolerance of the species. They are frequently isolated from the core population due to habitat fragmentation, thus manifesting a reduced genetic diversity (Jump and Penuelas 2006; Vilà-Cabrera et al. 2019). The importance of marginal populations in the adaptation of trees to the ongoing climate change seems to be still undervalued (Alberto et al. 2013; Madeira et al. 2018). Phenotypic plasticity is considered to be the change in the expressed phenotype of a given genotype as a function of the environment (Scheiner 1993), and thus is commonly applied to test inter-provenance variation in climate adaptation. However, changes in phenotype could be the result of either genotypic adaptation or phenotypic plasticity. Phenotypic changes may be more or less adaptive, and, in turn, maladaptive or non-adaptive changes might occur as a result of stress (West-Eberhard 
2003; Merilä and Hendry 2014). Given the above considerations, studies focusing on the aspect of phenotypic plasticity in climate adaptation require careful and critical evaluation of the proposed conclusions.

The assessment of intraspecies variation in phenotypic plasticity requires experiments that investigate the growth responses of genetically diverse provenances of the same species under the same growth conditions. Common garden experiments of forest tree species are often used in provenance-specific inter-annual climate adaptation studies, although they rarely become a tool for investigations on intra-seasonal variation of growth reaction (Ježík et al. 2016; Suvanto et al. 2016; Klisz et al. 2019b). In the case of marginal populations, the role of the climatic conditions driving onset and the end of activity of growth meristems seems to be of particularly importance, as marginal populations are located at the limits of ecological niches (Rossi et al. 2008; Montwe et al. 2018). Thus, within marginal growth conditions, growth rate can be limited by warming-induced soil moisture deficit (Ren et al. 2019). Indeed, marginal populations' growth is prone to limiting climatic factors that can change according to their relative position across the distribution area of the species (Hacket-Pain et al. 2016). Common garden experiments collecting different marginal populations undergoing local adaptation to different limiting factors could be the key for understanding if and how the species will adjust to the future climates (Kreyling et al. 2014).

According to recent species distribution models, European beech (Fagus sylvatica L.) could potentially play a dominant role among the other late-successional species, due to its high potential for resilience and level of plasticity in populations (Dyderski et al. 2018; Sáenz-Romero et al. 2019). Nevertheless, the level of adaptation to climate change of marginal beech populations may vary depending on their location within the natural range of this species. Low elevation populations from the southern distribution might be threatened by the forecasting warming (Mátyás et al. 2010), while high elevation population could suffer from late frosts (Allevato et al. 2019). Accordingly, it is evident that marginal populations require special attention. At northern and north-eastern distribution range, the beech populations manifest growth plasticity and high competition ability (Bolte et al. 2007; Farahat and Linderholm 2018; Weigel et al. 2018). Even beech populations introduced outside its natural range seem able to adapt properly at second generation (Matisons et al. 2017) after a period of high sensitivity to unfavorable conditions (Krišāns et al. 2016). In turn, southernmost beech populations, more resistant to xylem embolism, may better cope with frequent droughts (Stojnic et al. 2017; Varsamis et al. 2019). Thus, although the issue of intraspecific variation in phenotypic plasticity of beech was recently widely explored, still little is known on provenances from the south-eastern margin of the distribution range (Rose et al. 2009; Kramer et al. 2017).

Stem size variation is the cumulative result of the reversible elastic changes in phloem and cambium caused by transpiration and the irreversible xylem growth due to expansion of new cells (Deslauriers et al. 2007; Nalevanková et al. 2018). There are evidences that several environmental factors regulate the processes occurring within the stem, manifesting in intra-annual changes in its size (e.g. Köcher et al. 2012; Siegmund et al. 2016; Schäfer et al. 2018). The onset of stem size variation mostly depends on spring temperature and its accumulation over a longer period (Ježík et al. 2011). Moreover, thermal thresholds for the onset and ending of xylogenesis seem to be of importance for xylem production and maturation (Liang and Camarero 2018). However, extremely high temperatures in late spring and early summer cause sharp drop in stem-size curve. Solar radiation influences the hydrological conditions of beech stands, thus eventually causing a shortage of water during summer (Gessler et al. 2001). Furthermore, soil water shortage in late summer along with transpiration due to high temperature may negatively affect leaf water potential (Köcher et al. 2009) and indirectly stem circumference (Betsch et al. 2011). Droughtinduced changes in stem circumference result from stem water depletion, when trees are not able to refill elastic tissues, namely phloem, cambium, and subero-phelloderm.

Given the forecasting climate change and resulting shift of ecological niches, the beech is expected to expand not only beyond its current north-eastern, but also south-eastern distribution margin (Saltré et al. 2015; van der Maaten et al. 2017). Moreover, the ongoing changes in environmental conditions could affect more dramatically the populations located at the boundary of the species distribution. Nevertheless, despite reduced genetic diversity (Carsjens et al. 2014), marginal populations may manifest a higher plasticity to adapt to changing conditions (Valladares et al. 2014). However, recent studies carried out at the beech population level revealed relatively high inter-family phenotypic variability in growth and functional traits observed on beech common garden studies (Aranda et al. 2017). In this context, two questions arise (1) if and how climate sensitivity varies between marginal populations belonging to eastern margins of beech distribution range; and (2) whether climate-growth reaction is uniform within a given marginal population.

In this study, we investigated stem circumference variation of marginal populations of European beech growing in a common garden located at the south-eastern distribution of the species in Poland over a three-year period 2016-2018. We expect to detect a higher variability in stem circumference variation within provenances rather than between provenances. 


\section{Materials and methods}

\section{Study site and provenance selection}

This study is based on a beech common garden experiment located in Oleszyce, south-eastern Poland (N 54.0788 ${ }^{\circ}$, E $13.4787^{\circ}, 135 \mathrm{~m}$ a.s.1.), eastern margin of the European beech distribution range $\left(8.5^{\circ} \mathrm{C}\right.$ mean annual temperature and $609 \mathrm{~mm}$ annual precipitation, Fig. 1) (NOAA/NCEI/ CWC, http://www.noaa.gov/). The experiment was established in 2006 under coordination of State Forests National Forest Holding and composed of 24 provenances covering the south-eastern distribution range of beech in Poland. Marginal environmental conditions refer to climatic properties that represent the climatic margins of a species distributional range (Mellert et al. 2016). Accordingly, we considered our beech population to be marginal due to the fact that the climatic conditions in which they are located are similar to the marginal climatic conditions of beech population from the edge of south-eastern distribution of the species in western Ukraine. Provenance trial was located on leached brown soil in a complete block design with four replications. Each population was represented by 400 planted seedlings ( 100 per replication) planted in $1.5 \times 1.5 \mathrm{~m}$ spacing. Four provenances and with each of them, two to four co-dominant trees were selected to monitor stem circumference variation (SCV) from 2016 to 2018 (Fig. 1). Provenance selection aimed at representing highest possible diversity of climatic conditions of their origin in relation to the eastern distribution range $\left(\Delta \mathrm{MAT}=1.4{ }^{\circ} \mathrm{C}, \Delta \mathrm{MAP}=160 \mathrm{~mm}\right.$; Fig. S2). The number of trees measured changed in time with two trees per provenance investigated in the first year (2016) and five in the successive year. However, the target trees had to be successively reduced due to technical problems with the sensors, or damages caused by rodents (see Fig. 2).

\section{Dendrometer data}

The SCV was recorded from February 2016 to December 2018 using automatic band dendrometers (UMS D6
Fig. 1 Location and climate of the provenance trial in Oleszyce (blue triangle) and the beech provenances selected from south-eastern Poland (red dots). Top-left panel: climatic diagrams for Oleszyce trial. Top-right panel: distribution of European beech (EUFORGEN 2009)

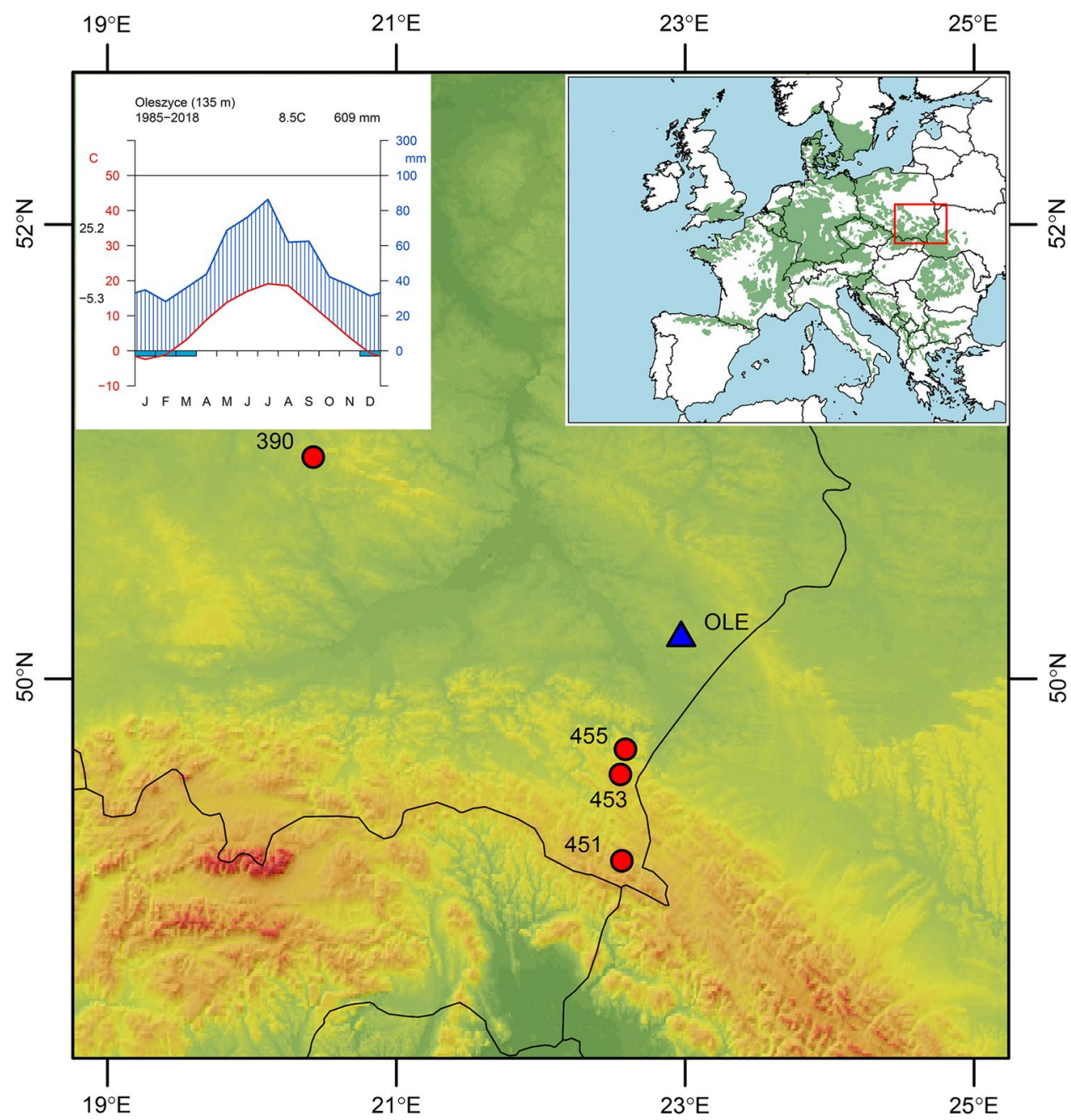




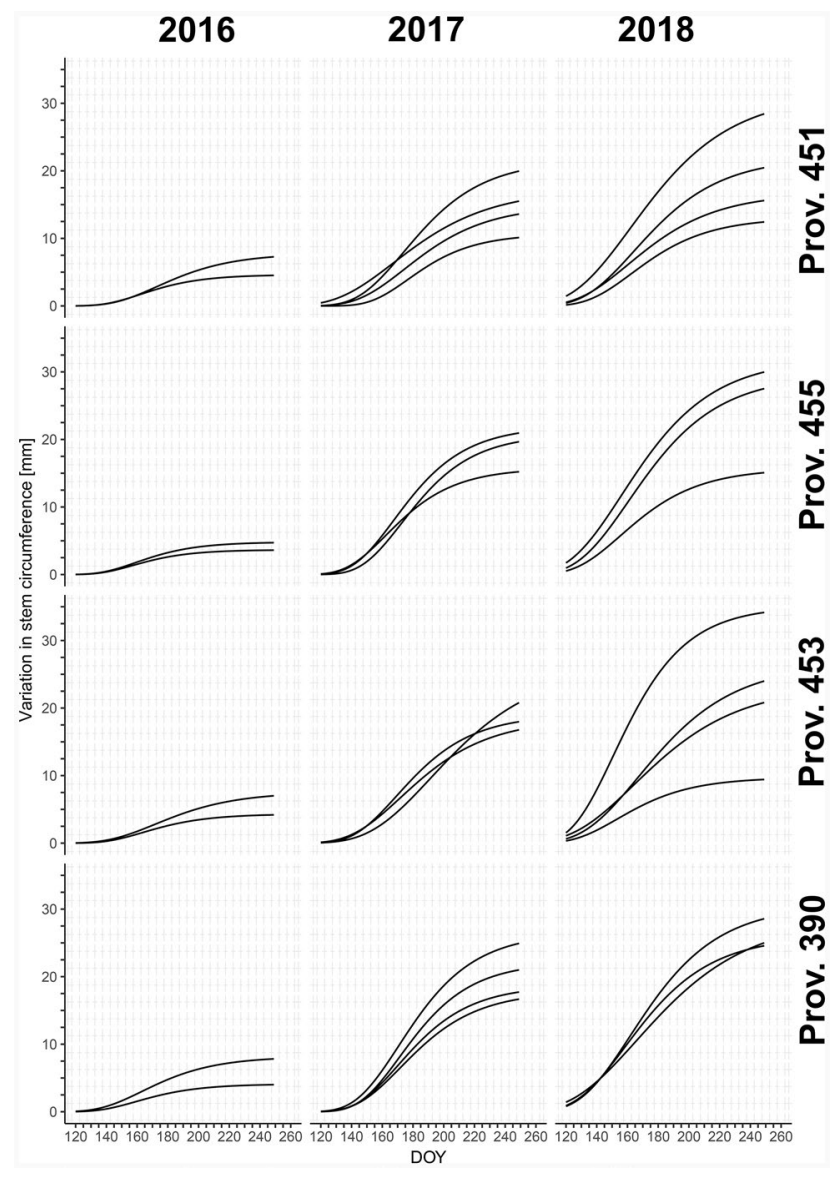

Fig. 2 Variation in stem circumference. Gompertz model functions were fitted to the experimental data of each tree

tree growth-sensor strain gage clip sensor). Due to the low branching, the dendrometers were installed at heights ranging from 1.0 to $1.3 \mathrm{~m}$. The daily means of SCV were calculated from measurements taken at 30-min intervals with $5 \mu \mathrm{m}$ accuracy and stored in automatic data loggers (DeltaT Devices GP2 Data Logger). To be able to describe SVC between years, a common interval was selected from each annual record corresponding to a general growth period reported in the literature between the day of the year (DOY) 120 and 249 (Prislan et al. 2019). Each dendrometer series was rescaled to start from the beginning of growth in circumference on DOY 120 (van der Maaten et al. 2018).

\section{Weather data}

Environmental data was monitored both on-site and nearby climate station on Oleszyce State Forest Nursery (at a distance of $380 \mathrm{~m}$ from target trees). On-site weather monitoring covered mean temperature, relative humidity, precipitation, photosynthetically active radiation ("S-THB" air temperature, "S-RGB" precipitation sensor connected to a "HOBO U30-NRC Analog Data Logger"; Onset Computer
Corporation, Bourne, USA) at 30-min intervals. Missing data in on-site weather monitoring were filled with the data from climate station on Oleszyce State Forest Nursery. The daily means of air temperature and sum of precipitation were calculated from measurements taken at 30-min intervals.

\section{Climatic and bioclimatic conditions}

To characterize contrasting weather conditions during the study period, namely months with water shortage due to above average air temperature and precipitation depletion and monthly anomalies for air temperature and precipitation (recorded on on-site weather station) were determined as relative to mean climate conditions in the period 1985-2018 [National Oceanic and Atmospheric Administration Agency (NOAA/NCEI/CWC1)].

To describe the distance between the climate of provenance origins and the trial site, a principal component analysis (PCA) of four bioclimatic parameters, namely mean annual temperature, temperature seasonality, annual precipitation, and precipitation seasonality was performed. Climatic parameters for Oleszyce provenance trial (OLE) site as well as for the climate of four beech provenances origin were extracted from BIOCLIM 1.4 (Hijmans et al. 2005) at a spatial resolution of 2.5 arcmin for the period 1970-2000. The variables with the strongest impact on the distribution of beech population and OLE trial site on PCA biplot was identified on the basis of Pearson correlation coefficients. Spatial variability of each climatic parameter within study region was visualized on four bioclimatic maps. On each map, location of trial site as well as for the four beech provenances was marked.

\section{Seasonal SCV dynamics}

To describe temporal pattern in SCV, the dendrometer series were fitted with Gompertz functions defined by Rossi et al. (2003) as:

$y=a \times \exp \left[-\exp ^{(\beta-k \times t)}\right]$,

where $y$ is the re-scaled daily stem circumference, $t$ is the time in form of DOY, $a$ is the upper asymptote, $\beta$ is the $\mathrm{X}$-axis placement parameter, and $k$ is the growth rate of the curve. The goodness-of-fit for each curve was assessed using the distribution of their studentized residuals. In our study, we adopted the arbitrary $5 \%$ and $95 \%$ of the upper asymptote as a threshold for the timings of onset and end of SCV (Van der Maaten et al. 2013), as according to Hennhapl et al. (1965) most of the growth of beech trees takes place during this period. The growth duration was calculated as a difference between end and onset of SCV. The estimated variables were used to determine the effect of year, provenance, and tree (nested within the provenance) on the total variance in 
stem circumference variation. General linear models (GLM) were used with $F$ test for type 3 analysis (Liang and Zeger 1986).

$G_{i j k}=\mu+Y_{i}+P_{j}+T_{k}\left(P_{j}\right)+\varepsilon_{i j k}$,

where $G_{i j k}$ is the Gompertz model's parameter in the $i$ th year $(i=1, \ldots, Y)$ for the $j$ th provenance $(j=1, \ldots, P)$ and in the $k$ th tree $(k=1, \ldots, T), \mu$ is the general mean, $Y_{i}$ is the effect of the $i$ th year, $P_{j}$ is the effect of the $j$ th provenance, $T_{k}\left(P_{j}\right)$ is the effect of the $k$ th tree in the $j$ th provenance, and $\varepsilon_{i j k}$ is the effect of experimental error. Multiple pairwise $t$ tests were performed to assess the differences between years. To control the family wise error rate, which may occur in the multiple comparison approach, a Holm correction was applied (Holm 1979). Reduced major axis (RMA) regressions were fitted to assess the relationships between curve's parameter and the duration of the SCV (Smith 2009). PCA analysis was applied to investigate the effect of monthly climate parameters, mean temperature, and precipitation sum of the growing season (April-September) on the Gompertz parameters.

All analyses were computed in "R" (R Core Team 2017). General linear models calculations were done with "car" package (Fox and Weisberg 2011). Gompertz function fitting and pairwise $t$ test were performed with "stats" package (R Core Team 2017). PCA analyses as well as the biplot were created with "factoMineR" package (Husson et al. 2015). RMA regressions were performed using the "smatr" package (Warton et al. 2012).

\section{Results}

\section{Seasonal SCV}

SCV were characterized by relatively uniform patterns, mainly in the provenances 453 and 455 in 2017 (Fig. 2). The good fitting of the Gompertz equation was confirmed by the symmetrical distribution of their studentized residuals and their respective values. The studentized residuals were indeed located within the -2 to 2 range in the $97 \%$ of the cases (Fig S1). Overall, SCV increased slowly in spring between DOY 120 and 140. A quicker increase was observed during the first part of summer, mainly in the period ranging between DOY 160 and 200. After which, the growth rate of SCV reduced until reaching a plateau. The plateau was attained in summer, on DOY 220-250.

GLM revealed the significant effect of year on SCV for all the studied variables (Table 1). No significant influence was confirmed in terms of provenance, and only partially (namely, the variables $a, k$ and end) for tree effect. The majority of the total variability was explained by either year (onset and end) or tree ( $a$ and duration of SCV). However, both effects were equally responsible for the overall variability of $k$. Linear regression highlighted not only the stable and similar relationship between the coefficient $a$, but also duration and onset with end of SCV (Fig. 3). However, as the $R^{2}$ values were lower than 0.5 , we can only confirm these relationships as trends. Together with the later ending of SCV, both upper asymptote and duration increases, although onset of SCV seems to be marginal to these parameters. In turn, for $k$ and onset with end, the opposite pattern can be observed. That is, together with later onset and earlier ending of SCV, $k$ increases. For the end parameter and to a lesser extent for onset (relationship with $a$ ), points are more dispersed, mainly for higher asymptotic values. In turn, onset and end points are highly concentrated around the regression line. In particular, the largest differences between years were observed between 2017 and 2018 (Fig. 4). Onset parameter of 2018 differed significantly from 2016 to 2017, while no differences were detected between 2016 and 2017 . In turn, end and upper asymptote in 2017 differed from 2016 to 2018 .

\section{Climate-shift effect}

Climatic conditions of study period were characterized by shortage of precipitation, except for June 2018 and September 2017. In respect to the long-term average, warmer conditions were observed in September 2016, March 2017, and April and August 2018 (Fig. 5). Bioclimatic parameters of provenance origins and trial site reduced to the two dimensions allowed to detect a provenance cluster between 453 and 455 , confirming their similarity in terms of climate
Table 1 Results of generalized linear models to test the differences in upper asymptote $(a)$, growth rate $(k)$, onset, end and duration of SCV due to year, provenance and tree with $\mathrm{F}$ test for type 3 analysis

\begin{tabular}{|c|c|c|c|c|c|c|c|c|c|c|c|c|c|c|}
\hline \multirow[t]{2}{*}{ Source of variation } & \multicolumn{4}{|c|}{ Year } & \multicolumn{4}{|c|}{ Provenance } & \multicolumn{4}{|c|}{ Tree (provenance) } & \multirow[t]{2}{*}{$F$} & \multirow[t]{2}{*}{$R^{2}$} \\
\hline & $D f$ & $F$ & $P$ & $\%$ & $D f$ & $F$ & $P$ & $\%$ & $D f$ & $F$ & $P$ & $\%$ & & \\
\hline$a$ & 2 & 25.24 & $<0.001$ & 31 & 3 & 3.09 & 0.055 & 4 & 15 & 4.41 & 0.002 & 65 & 10.97 & 0.93 \\
\hline$k$ & 2 & 16.70 & $<0.001$ & 49 & 3 & 2.21 & 0.125 & 1 & 15 & 2.99 & 0.016 & 50 & 5.03 & 0.86 \\
\hline onset & 2 & 63.84 & $<0.001$ & 75 & 3 & 1.11 & 0.3734 & 1 & 15 & 1.65 & 0.161 & 24 & 7.97 & 0.90 \\
\hline end & 2 & 4.64 & 0.025 & 64 & 3 & 2.55 & 0.090 & 2 & 15 & 3.11 & 0.014 & 35 & 3.57 & 0.81 \\
\hline duration & 2 & 12.91 & $<0.001$ & 48 & 3 & 1.59 & 0.229 & 1 & 15 & 2.47 & 0.038 & 51 & 3.80 & 0.82 \\
\hline
\end{tabular}

$D f$ degrees of freedom, $F$ test statistic, $P p$ value, $R^{2}$ coefficient of determination, $\%$ variance explained 

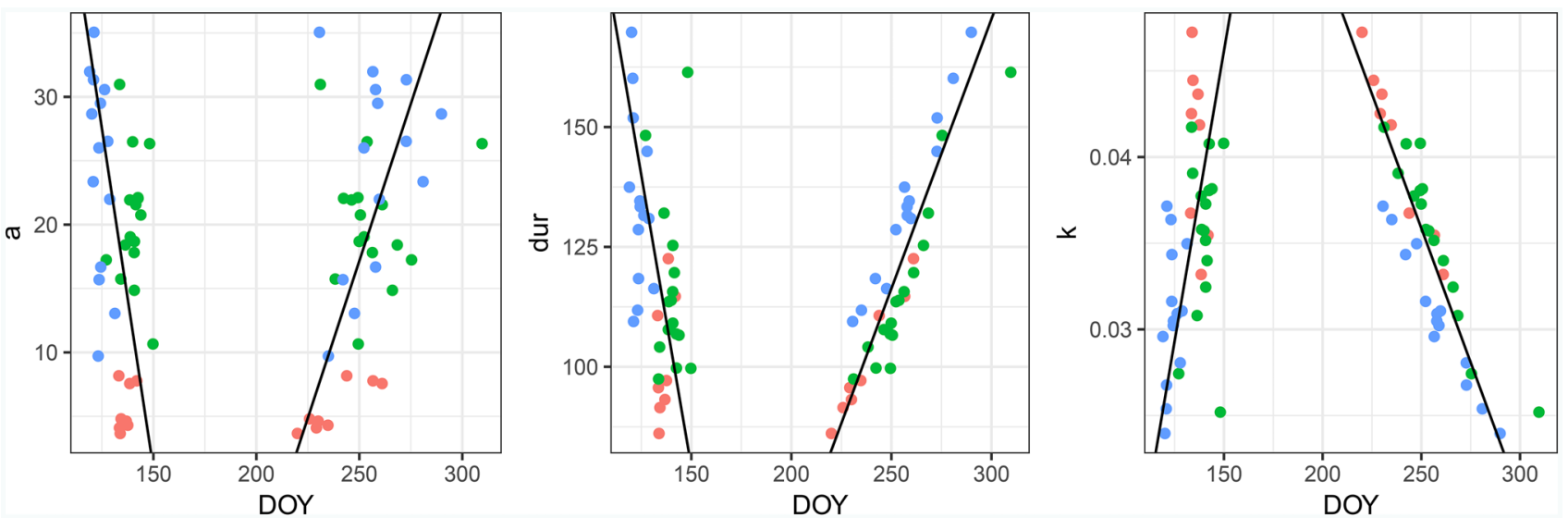

Fig. 3 The effect of upper asymptote (a), duration of growth (dur) and growth rate $(k)$ on onset and end of stem radial displacement. Color code assigned for years (red: 2016, green: 2017, blue: 2018)

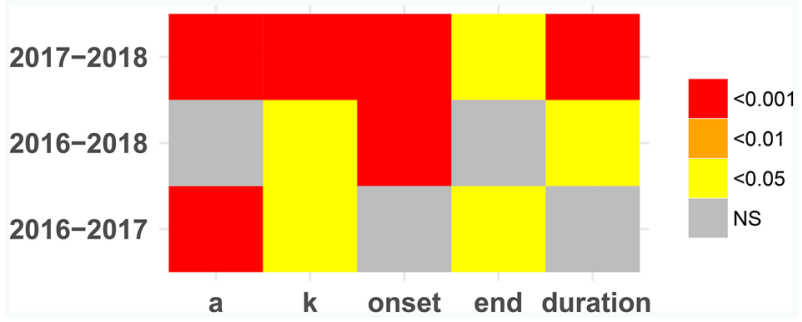

Fig. 4 Pairwise comparisons between years 2016 and 2018 for upper asymptote $(a)$, growth rate $(k)$, onset, end and duration of SCV

origin (Fig. 6). Provenances 390 and 451 were located on the periphery of the PC biplot, indicating their distinct position in relation to the provenance cluster and OLE trial site. First principal components (PC1) explained $82.64 \%$ of the overall variance and positively correlated $(r>0.98)$ with annual precipitation (bio12) and negatively correlated $(-0.92<r<-1)$ with mean annual temperature and precipitation seasonality (bio1, bio15) (Fig. 6, Table 2). Thus, provenances 390 and 451 differ from OLE study site, mainly in temperature and precipitation seasonality (451), but also mean annual temperature (390).

\section{Climate-SCV relationship}

PCA of main climatic parameters of growing season reveals that duration, end and the upper asymptote $a$ were positively correlated with August temperature and, at a less extent, with August precipitation. The parameter $k$ showed the same relationships, but with negative correlations (Fig. 7, Table S1). Positive correlation was observed between $k$ and June temperature and April precipitation. Onset was strongly and negatively related to spring (April and May)
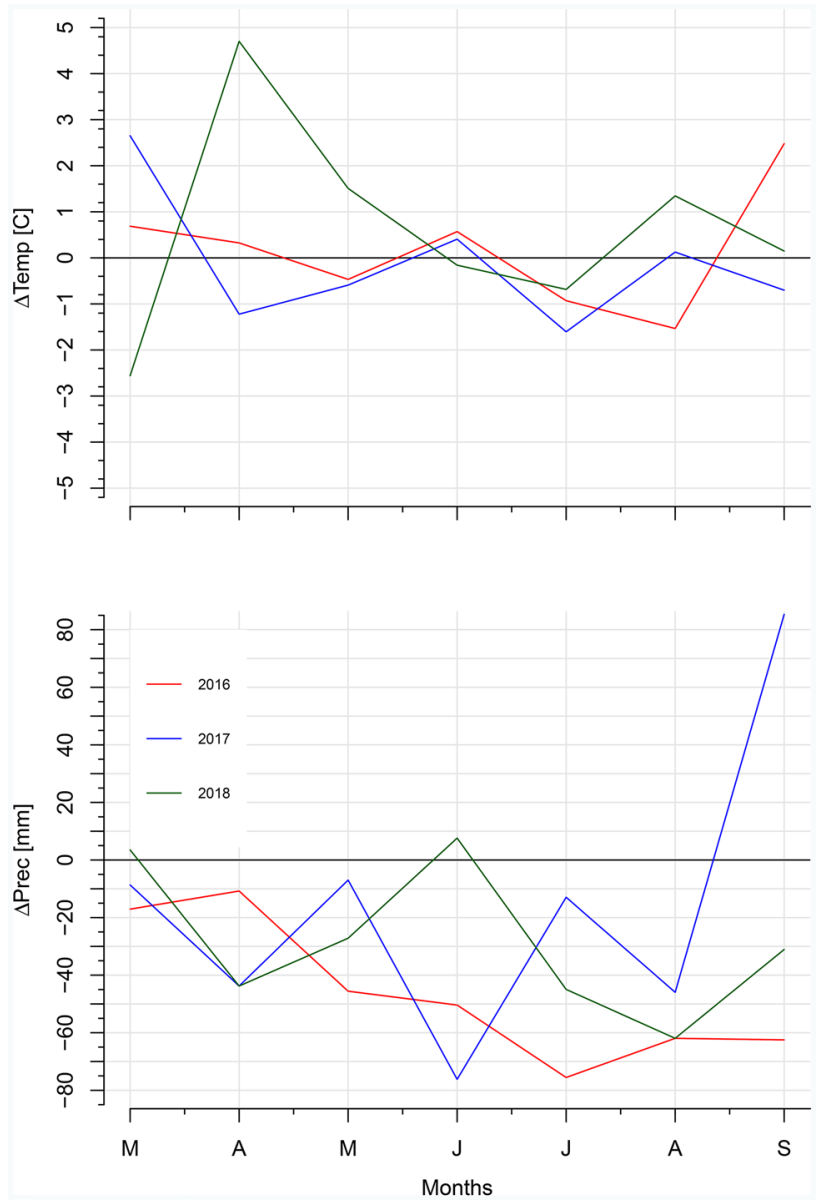

Fig. 5 Anomalies for monthly air temperature (upper panel) and precipitation (lower panel) for the years 2016-2018 as relative to mean climate conditions in the period 1985-2018

temperature. Clustering highlighted the dominant effect of between-years variation, while the effect of provenance was marginal. 


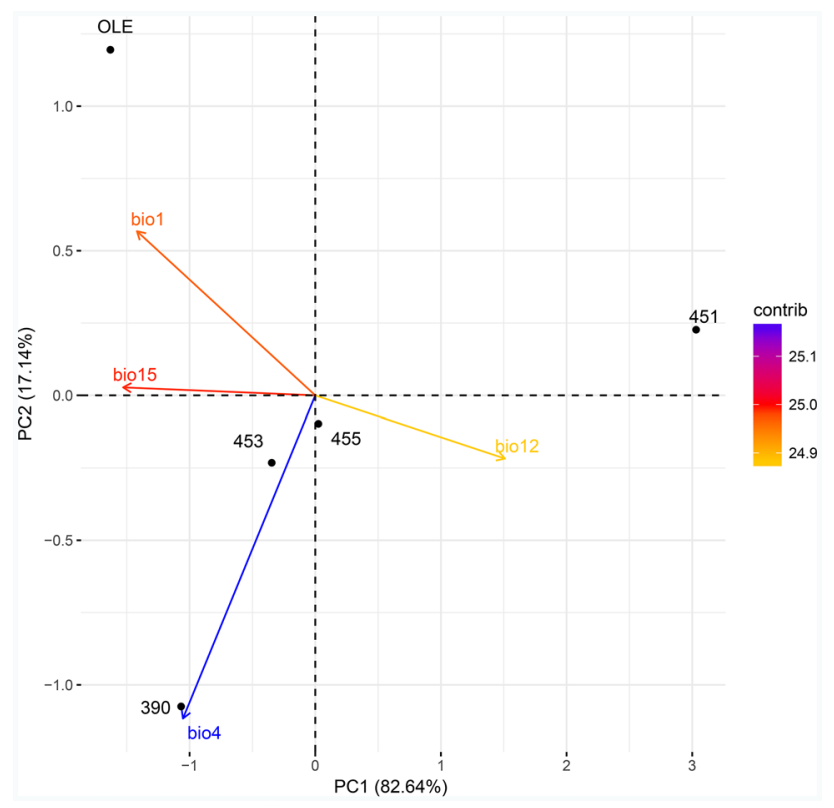

Fig. 6 Climate-related variability between provenances (390, 451, 453, and 455) and experimental site (OLE) based on four bioclimatic indexes: bio1: mean annual temperature, bio4: temperature seasonality, bio12: annual precipitation, bio15: precipitation seasonality. Variables vector color according to their contribution in total variance: orange: low, blue: high

Table 2 Pearson's correlation coefficients between climatic variables and the first two major components and contribution of variables in principal components

\begin{tabular}{lcrlll}
\hline $\begin{array}{l}\text { Bioclimatic vari- } \\
\text { ables }\end{array}$ & \multicolumn{2}{l}{ Pearson's correlation } & & \multicolumn{2}{l}{$\begin{array}{l}\text { Contribution in PCs } \\
(\%)\end{array}$} \\
\cline { 2 - 3 } \cline { 5 - 6 } & PC1 & PC2 & & PC1 & PC2 \\
\hline bio1 & -0.92 & 0.37 & & 26.01 & 19.92 \\
bio4 & -0.69 & -0.73 & & 14.32 & 77.1 \\
bio12 & 0.98 & -0.14 & & 29.46 & 2.93 \\
bio15 & -1 & 0.02 & & 30.2 & 0.05 \\
\hline
\end{tabular}

\section{Discussion}

The study confirms our hypothesis that the variability between beech trees in stem circumference variation (SCV) is higher than that between provenances. Moreover, end of SCV affects positively the duration and amplitude of SCV and affects negatively the growth rate. Spring temperature was the main climatic driver of the onset, while temperature and precipitation of summer months influenced end, duration, and amplitude of SCV. Accordingly, the relatively dry and warm conditions occurring in spring 2018 advanced the onset in SCV.

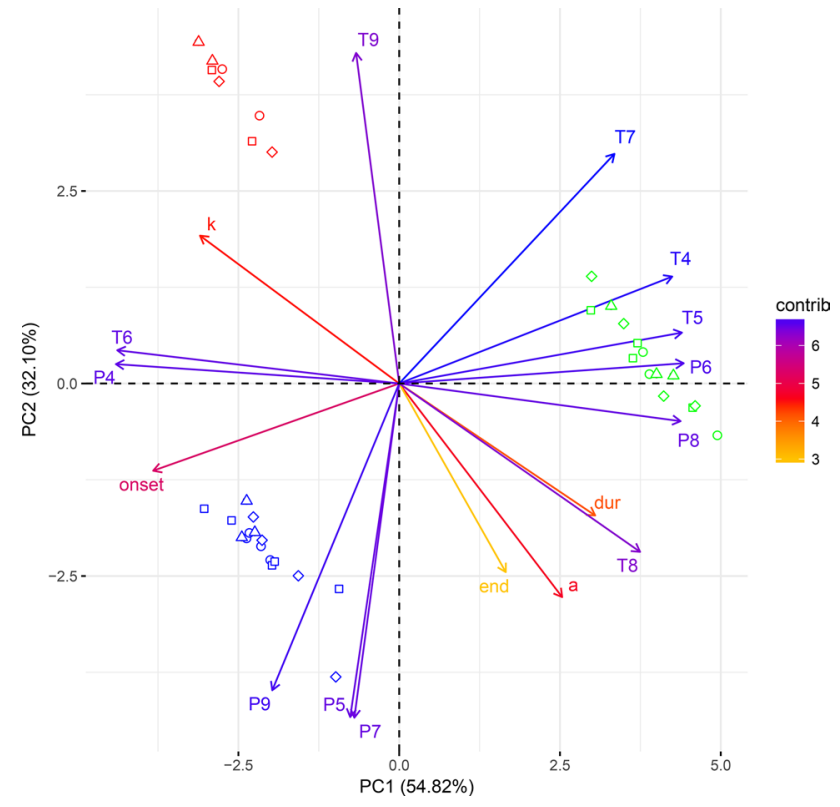

Fig. 7 Principal component analysis of climatic parameters: temperature (T4-T9) and precipitation (P4-P9) of April-September and growth parameters: upper asymptote, growth rate, onset, end and duration of $\operatorname{SCV}$ ( $a, k$, duration, onset and end, respectively). Variables vector color according to their contribution in total variance: orange: low, blue: high. Individual trees assigned in relations to provenance (390: circle, 451: square, 453: diamond, 455: triangle) and years (2016: red, 2017: blue, 2018: green)

\section{Genetic effect in beech populations}

Intra-specific gradients of beech are commonly available in the literature (Stojnić et al. 2017; Cocozza et al. 2016; Bolte et al. 2016; Ježík et al. 2016; Buhk et al. 2016; Harter et al. 2015). However, the majority of them focus on the southern, western, and/or northern margins of beech distribution range. Only a few of them have included populations from the northern or eastern distribution range and, when included, only one marginal population was analyzed, thus preventing to assess the phenotypic variability for representative groups (Kolár et al. 2017; Kurjak et al. 2018; Weigel et al. 2018; Rose et al. 2009). Our study covered northern part of the south-eastern boundary of the biogeographic range of beech, revealing that intra-population variability oversteps inter-population variability of seasonal SCV, regardless of dry or wet growing seasons (Table 1). Despite the geographic isolation of a provenance, named 390 , it seems likely that gene flow between marginal and central distribution range is able to balance the isolationby-distance effect in genetic structure (Leonardi et al. 2012). Thus, relatively low differences between population variability in seasonal SCV seem to correspond with the previous studies on beech marginal populations (Aranda et al. 2017; Stojnić et al. 2017). Although Stojnić et al. (2017) 
confirmed significant differences between provenances in resistance to embolism, they concerned differences between marginal populations from marginal sites covering a larger geographical and climatical area than the populations analyzed in this study.

\section{Climate-transfer effect}

Due to the climate-transfer-related constrains in studying provenance adaptability on common garden experiments, resulting from possible maladaptation of populations or diminishing effect of marginal site conditions (Klisz et al. 2018, 2019a), we applied multi-dimensional analysis of bioclimatic parameters. Two-object clusters (provenances 453 and 455), located closest to the provenance trial, would suggest a better adaptation of these two populations to the growing conditions than the provenances 390 and 451, which are climatically more distant. However, results of general linear models (Table 1) provide no basis for such an interpretation. According to Stojnić et al. (2013), beech populations from relatively moist environments are able to cope with drier conditions. Hence, provenance 451 from clearly wetter but also colder conditions (Table 2, Fig. S2) might seem to be predisposed to a plastic reaction in the conditions of OLE site. While provenance 390, from warmer but also similar in terms of annual precipitation conditions, would suffer from late frost due to significantly different temperature seasonality (Table 2; Kramer et al. 2017). Despite the clear provenance differentiation in climate of provenance origin as well as climate transfer (difference in bioclimatic conditions between the provenances and provenance trial), the effect of provenance does not seem to play a role in SCV (Table 1). These results are consistent with previous studies covering a wider group of beech provenance, where the betweenprovenances variation in stem circumference increase was diminished due to high within-provenance variation (Ježík et al. 2016). Such a high between-individuals variability was widely reported in studies on natural populations and common garden experiments; however, they mainly concerned inter-annual growth variation (Stojnić et al. 2013; Weigel et al. 2018). Indeed, they rarely included more than six trees of a given population; therefore they may not fully represent within-provenance phenotypic variation.

\section{Inter-annual SCV in relations to climate}

Weather conditions affected the variation in stem size, as reflected in the onset, end and upper asymptote of the Gompertz functions describing seasonal pattern in SCV. Significant differences between years in onset of SCV along with the opposite trends in temperature anomalies of March, April, and May correspond with recent studies on xylem formation in beech (Prislan et al. 2019). The authors observed indeed positive correlations between temperatures of March-May and the spring phenological phases in Slovenia. In our study, strong differences in onset between 2017 and 2018 and between 2017 and 2016 are not reflected in the precipitation anomalies. The above findings are in accordance with recent studies on cambial phenology, confirming that precipitation is not a limiting factor during xylogenesis of beech within its natural distribution (Prislan et al. 2018).

A distinct trend between end of SCV and the upper asymptote, which could be considered as a proxy of the radial expansion of the stem, seems to be consistent with studies on xylem formation in beech (Čufar et al. 2008; Vavrčík et al. 2013; Semeniuc et al. 2014). Nevertheless, the reversible shrinkage and expansion of the stem related to the changes in water content of outermost tissues should be taken carefully into account, when SCV amplitude is interpreted (Zweifel 2016). According to the above-mentioned studies, maximum cell production takes place between the end of May and July. Therefore, later end of SCV may indicate extension of duration of cell division and cell enlargement. As cell enlargement seems to be related to July precipitation (Čufar et al. 2008), the differences observed for the end in SCV between 2017 and the other 2 years may be explained by the divergent pattern in summer precipitations. Still, the range of end values in the season 2018 (relationship with $a$ ) remains difficult to explain based on the climate parameters.

Duration of SCV is mainly dependent on the end, and not onset, in SCV, which is partly reflected in the period of maximum cell production (Čufar et al. 2008; Vavrčík et al. 2013; Semeniuc et al. 2014). In contrast, growth rate manifests an opposite, with later onset and earlier end observed with faster growth rate (Fig. 3). These relationships suggest that growth rate increases with shorter durations of SCV, which suggest the opposite to the compensatory mechanism described by Balducci et al. (2016). The relationships between climate anomalies and Gompertz functions parameters are consistent with the multi-dimensional analysis of monthly climate and SCV parameters (Fig. 7, Table S1). The same relationships between climate and SCV parameters were observed in other studies on changes in intraannual stem diameter of beech, regardless of study period, tree age, and study site locations, (Ježík et al. 2011, 2016; Van der Maaten et al. 2013). However, the high sensitivity to climate anomalies may result from the young age of the trees or/and prolonged vegetation periods reported for young trees (Trouillier et al. 2019). Thus, during our study period 2016-2018, the spring and summer temperatures and to a lesser extent summer precipitation seem to be the common climatic drivers of stem variation for all beech provenances. 


\section{Conclusions}

Our study investigated the effect of provenance on intraannual stem circumference variation (SCV) under a beech common garden experiment. It was suggested that the variability in stem circumference variation within provenances masked the variation between provenances. Our study revealed that within marginal beech populations, the intra-annual variability in stem size was higher within than between populations. Spring temperature as well as summer temperature and precipitation are the main climatic drivers of the onset, end, and amplitude of SCV. This suggests that intra-provenance variation in stem size may become more pronounced with the increase in the frequency of climate anomalies expected in the next decades. Considering these conditions, individual-based rather then population-based approach should be applied when breeding marginal beech populations.

Author contribution statement $\mathrm{MK}$ and $\mathrm{SJ}$ were responsible for data collection; MK, VB, and SR performed all statistical analysis; MK wrote the manuscript; MK, VB, SR, HM, and SJ were involved in text corrections. All the authors read and approved the final manuscript.

Acknowledgements The study was funded by the State Forests National Forest Holding, as part of research project BLP-375. This paper was developed under a granted scholarship within Scholarship Fund of the Forest Research Institute, pursuant to the decision of the Head of the Institute dated 17th October, 2018 (based on an Agreement concluded on 18th October, 2018).

\section{Compliance with ethical standards}

Conflict of interest The authors declare that they have no conflict of interest.

Open Access This article is distributed under the terms of the Creative Commons Attribution 4.0 International License (http://creativeco mmons.org/licenses/by/4.0/), which permits unrestricted use, distribution, and reproduction in any medium, provided you give appropriate credit to the original author(s) and the source, provide a link to the Creative Commons license, and indicate if changes were made.

\section{References}

Alberto FJ, Aitken SN, Alía R et al (2013) Potential for evolutionary responses to climate change-evidence from tree populations. Glob Chang Biol 19:1645-1661. https://doi.org/10.1111/ gcb.12181

Allevato E, Saulino L, Cesarano G et al (2019) Canopy damage by spring frost in European beech along the Apennines: effect of latitude, altitude and aspect. Remote Sens Environ 225:431-440. https://doi.org/10.1016/j.rse.2019.03.023
Aranda I, Bahamonde HA, Sánchez-Gómez D (2017) Intra-population variability in the drought response of a beech (Fagus sylvatica L.) population in the southwest of Europe. Tree Physiol 37:938-949. https://doi.org/10.1093/treephys/tpx058

Balducci L, Cuny HE, Rathgeber CBK et al (2016) Compensatory mechanisms mitigate the effect of warming and drought on wood formation. Plant Cell Environ 39:1338-1352. https://doi. org/10.1111/pce.12689

Betsch P, Bonal D, Breda N et al (2011) Drought effects on water relations in beech: the contribution of exchangeable water reservoirs. Agric For Meteorol 151:531-543. https://doi.org/10.1016/j.agrfo rmet.2010.12.008

Bolte A, Czajkowski T, Kompa T (2007) The north-eastern distribution range of European beech-a review. Forestry 80:413-429. https ://doi.org/10.1093/forestry/cpm028

Bolte A, Czajkowski T, Cocozza C, et al (2016) Desiccation and mortality dynamics in seedlings of different European Beech (Fagus sylvatica $\mathrm{L}$.) populations under extreme drought conditions. Front Plant Sci 7:751. https://doi.org/10.3389/fpls.2016.00751

Buhk C, Kämmer M, Beierkuhnlein C et al (2016) On the influence of provenance to soil quality enhanced stress reaction of young beech trees to summer drought. Ecol Evol 6:8276-8290. https:// doi.org/10.1002/ece3.2472

Carsjens C, Ngoc QN, Guzy J et al (2014) Intra-specific variations in expression of stress-related genes in beech progenies are stronger than drought-induced responses. Tree Physiol 34:1348-1361. https://doi.org/10.1093/treephys/tpu093

Cocozza C, Vega MDM, Psidova E et al (2016) Variation in ecophysiological traits and drought tolerance of beech (Fagus sylvatica L.) seedlings from different populations. Front Plant Sci 7:886. https ://doi.org/10.3389/fpls.2016.00886

Core Team R (2017) R: A language and environment for statistical computing. R Foundation for Statistical Computing, Vienna

Čufar K, Prislan P, De Luis M, Gričar J (2008) Tree-ring variation, wood formation and phenology of beech (Fagus sylvatica) from a representative site in Slovenia, SE Central Europe. Trees Struct Funct 22:749-758. https://doi.org/10.1007/s00468-008-0235-6

DE Harter V, Nagy L, Backhaus S et al (2015) A comparison of genetic diversity and phenotypic plasticity among European Beech (Fagus sylvatica L.) populations from Bulgaria and Germany under drought and temperature manipulation. Int J Plant Sci 176:232244. https://doi.org/10.1086/679349

Deslauriers A, Anfodillo T, Rossi S, Carraro V (2007) Using simple causal modeling to understand how water and temperature affect daily stem radial variation in trees. Tree Physiol 27:1125-1136. https://doi.org/10.1093/treephys/27.8.1125

Dyderski MK, Pa S, Andrzej EF, Jagodzi M (2018) How much does climate change threaten European forest tree species distributions? Glob Chang Biol 24:1150-1163. https://doi.org/10.1111/ gcb. 13925

EUFORGEN, (2009) Distribution Map of European beech. http://www. euforgen.org

Farahat E, Linderholm HW (2018) Growth-climate relationship of European beech at its northern distribution limit. Eur J For Res 137:619-629. https://doi.org/10.1007/s10342-018-1129-9

Fox J, Weisberg S (2011) An R companion to applied regression, second. Sage, Thousand Oaks

Gessler A, Schrempp S, Matzarakis A et al (2001) Radiation modifies the effect of water availability on the carbon isotope composition of beech (Fagus sylvatica). New Phytol 150:653-664. https://doi. org/10.1046/j.1469-8137.2001.00136.x

Hacket-Pain AJ, Cavin L, Friend AD, Jump AS (2016) Consistent limitation of growth by high temperature and low precipitation from range core to southern edge of European beech indicates widespread vulnerability to changing climate. Eur J For Res 135:897-909. https://doi.org/10.1007/s10342-016-0982-7 
Hennhapl G (1965) Über die Stärkeänderung der peripheren Stammzone von Wald-bäumen im Jahresverlauf. Albert-LudwigsUniversity, Freiburg

Hijmans RJ, Cameron SE, Parra JL et al (2005) Very high resolution interpolated climate surfaces for global land areas. Int J Climatol 25:1965-1978. https://doi.org/10.1002/joc.1276

Holm S (1979) A simple sequentially rejective multiple test procedure. Scand J Stat 6:65-70

Husson F, Josse J, Le S, Mazet J (2015) Factominer: multivariate exploratory data analysis and data mining. $\mathrm{R}$ package version 1:29

Ježík M, Blaženec M, Střelcová K, Ditmarová L (2011) The impact of the 2003-2008 weather variability on intra-annual stem diameter changes of beech trees at a submontane site in central Slovakia. Dendrochronologia 29:227-235. https://doi.org/10.1016/j.dendr o.2011.01.009

Ježík M, Blaženec M, Kučera J et al (2016) The response of intraannual stem circumference increase of young European beech provenances to 2012-2014 weather variability. IForest 9:960-969. https://doi.org/10.3832/ifor1829-009

Jump AS, Penuelas J (2006) Genetic effects of chronic habitat fragmentation in a wind-pollinated tree. Proc Natl Acad Sci 103:80968100. https://doi.org/10.1073/pnas.0510127103

Klisz M, Ukalski K, Ukalska J et al (2018) What can we learn from an early test on the adaptation of silver fir populations to marginal environments? Forests 9:441. https://doi.org/10.3390/f9070441

Klisz M, Buras A, Sass-Klaassen U et al (2019a) Limitations at the limit? Diminishing of genetic effects in Norway Spruce provenance trials. Front Plant Sci 10:306. https://doi.org/10.3389/ fpls.2019.00306

Klisz M, Ukalska J, Koprowski M et al (2019b) Effect of provenance and climate on intra-annual density fluctuations of Norway spruce (Picea abies L.) in Poland. Agric For Meteorol 269-270:145-156. https://doi.org/10.1016/j.agrformet.2019.02.013

Köcher P, Gebauer T, Horna V, Leuschner C (2009) Leaf water status and stem xylem flux in relation to soil drought in five broad-leaved tree species with contrasting water use strategies. Ann For Sci 66:101-106

Köcher P, Horna V, Leuschner C, Abrams M (2012) Environmental control of daily stem growth patterns in five temperate broadleaved tree species. Tree Physiol 32:1021-1032. https://doi. org/10.1093/treephys/tps049

Koláŕ T, Čermák P, Trnka M et al (2017) Temporal changes in the climate sensitivity of Norway spruce and European beech along an elevation gradient in Central Europe. Agric For Meteorol 239:2433. https://doi.org/10.1016/j.agrformet.2017.02.028

Kramer K, Ducousso A, Gömöry D et al (2017) Chilling and forcing requirements for foliage bud burst of European beech (Fagus sylvatica $\mathrm{L}$.) differ between provenances and are phenotypically plastic. Agric For Meteorol 234:172-181. https://doi.org/10.1016/j. agrformet.2016.12.002

Kreyling J, Buhk C, Backhaus S et al (2014) Local adaptations to frost in marginal and central populations of the dominant forest tree Fagus sylvatica $\mathrm{L}$. as affected by temperature and extreme drought in common garden experiments. Ecol Evol 4:594-605. https://doi. org/10.1002/ece3.971

Krišāns O, Puriṇa L, Mesters D et al (2016) Intra-annual radial growth of European beech-a case study in north easternmost stand in Europe. For Stud 65:34-42. https://doi.org/10.1515/ fsmu-2016-0010

Kurjak D, Konôpková A, Kmet' J et al (2018) Variation in the performance and thermostability of photosystem II in European beech (Fagus sylvatica L.) provenances is influenced more by acclimation than by adaptation. Eur J For Res 138:79-92. https://doi. org/10.1007/s10342-018-1155-7
Leonardi S, Piovani P, Scalfi M et al (2012) Effect of habitat fragmentation on the genetic diversity and structure of peripheral populations of beech in central Italy. J Hered 103:408-417. https://doi. org/10.1093/jhered/ess004

Liang E, Camarero JJ (2018) Threshold-dependent and non-linear associations between temperature and tree growth at and below the alpine treeline. Trees 32:661-662. https://doi.org/10.1007/s0046 8-017-1651-2

Liang K-Y, Zeger SL (1986) Longitudinal data analysis using generalized linear models. Biometrika 73:13-22. https://doi.org/10.1093/ biomet/73.1.13

Madeira C, Ricardo DM, Herna E, Jose A (2018) Living on the edge: do central and marginal populations of plants differ in habitat suitability? Plant Ecol 219:1029-1043. https://doi.org/10.1007/ s11258-018-0855-x

Matisons R, Puriṇa L, Adamovičs A et al (2017) European beech in its northeasternmost stands in Europe: varying climate-growth relationships among generations and diameter classes. Dendrochronologia 45:123-131. https://doi.org/10.1016/j.dendro.2017.08.004

Mátyás C, Berki I, Czucz B et al (2010) Future of beech in Southeast Europe from the perspective of evolutionary ecology. Acta Silv Lignaria Hungarica 6:91-110

Mellert KH, Ewald J, Hornstein D et al (2016) Climatic marginality: a new metric for the susceptibility of tree species to warming exemplified by Fagus sylvatica (L.) and Ellenberg's quotient. Eur J For Res 135:137-152. https://doi.org/10.1007/s10342-015-0924-9

Merilä J, Hendry AP (2014) Climate change, adaptation, and phenotypic plasticity: the problem and the evidence. Evol Appl 7:1-14. https://doi.org/10.1111/eva.12137

Montwe D, Isaac-Renton M, Hamann A, Spiecker H (2018) Cold adaptation recorded in tree rings highlights risks associated with climate change and assisted migration. Nat Commun 9:1574. https ://doi.org/10.1038/s41467-018-04039-5

Nalevanková P, Ježík M, Sitková Z et al (2018) Drought and irrigation affect transpiration rate and morning tree water status of a mature European beech (Fagus sylvatica L.) forest in Central Europe. Ecohydrology 11:1-14. https://doi.org/10.1002/eco.1958

Prislan P, Čufar K, De Luis M, Gričar J (2018) Precipitation is not limiting for xylem formation dynamics and vessel development in European beech from two temperate forest sites. Tree Physiol 38:186-197. https://doi.org/10.1093/treephys/tpx167

Prislan P, Gričar J, Čufar K et al (2019) Growing season and radial growth predicted for Fagus sylvatica under climate change. Clim Change. https://doi.org/10.1007/s10584-019-02374-0

Ren P, Ziaco E, Rossi S et al (2019) Growth rate rather than growing season length determines wood biomass in dry environments. Agric For Meteorol 271:46-53. https://doi.org/10.1016/j.agrfo rmet.2019.02.031

Rose L, Leuschner C, Köckemann B, Buschmann H (2009) Are marginal beech (Fagus sylvatica L.) provenances a source for drought tolerant ecotypes? Eur J For Res 128:335-343. https:// doi.org/10.1007/s10342-009-0268-4

Rossi S, Deslauriers A, Morin H (2003) Application of the Gompertz equation for the study of xylem cell development. Dendrochronologia 21:33-39. https://doi.org/10.1073/pnas.1321727111

Rossi S, Deslauriers A, Griçar J et al (2008) Critical temperatures for xylogenesis in conifers of cold climates. Glob Ecol Biogeogr 17:696-707. https://doi.org/10.1111/j.1466-8238.2008.00417.x

Sáenz-Romero C, Kremer A, Nagy L et al (2019) Common garden comparisons confirm inherited differences in sensitivity to climate change between forest tree species. PeerJ 7:e6213. https:// doi.org/10.7717/peerj.6213

Saltré F, Duputié A, Gaucherel C, Chuine I (2015) How climate, migration ability and habitat fragmentation affect the projected future 
distribution of European beech. Glob Chang Biol 21:897-910. https://doi.org/10.1111/gcb.12771

Schäfer C, Thurm EA, Rötzer T et al (2018) Daily stem water deficit of Norway spruce and European beech in intra- and interspecific neighborhood under heavy drought. Scand J For Res 33:568-582. https://doi.org/10.1080/02827581.2018.1444198

Scheiner SM (1993) Genetics and evolution of phenotypic plasticity. Annu Rev Ecol Syst 24:35-68

Semeniuc A, Popa I, Timofte AI, Gurean DM (2014) Xylem phenology of Fagus sylvatica in rarău mountains (eastern carpathians, Romania). Not Bot Horti Agrobot Cluj-Napoca 42:275-279. https ://doi.org/10.1161/01.cir.0000437739.71477.ee

Siegmund JF, Sanders TGM, Heinrich I et al (2016) Meteorological drivers of extremes in daily stem radius variations of Beech, Oak, and Pine in Northeastern Germany: an event coincidence analysis. Front Plant Sci 7:733. https://doi.org/10.3389/fpls.2016.00733

Smith RJ (2009) Use and misuse of the reduced major axis for line-fitting. Am J Phys Anthropol 140:476-486. https://doi.org/10.1002/ ajpa. 21090

Stojnic S, Sass-Klaassen U, Orlovic S et al (2013) Plastic growth response of european beech provenances to dry site conditions. IAWA J 34:475-484. https://doi.org/10.1163/22941932-00000038

Stojnić S, Suchocka M, Benito-Garzón M et al (2017) Variation in xylem vulnerability to embolism in European beech from geographically marginal populations. Tree Physiol 38:173-185. https ://doi.org/10.1093/treephys/tpx128

Suvanto S, Nöjd P, Henttonen HM et al (2016) Geographical patterns in the radial growth response of Norway spruce provenances to climatic variation. Agric For Meteorol 222:10-20. https://doi. org/10.1016/j.agrformet.2016.03.003

Trouillier M, van der Maaten-Theunissen M, Scharnweber T et al (2019) Size matters-a comparison of three methods to assess age- and size-dependent climate sensitivity of trees. Trees Struct Funct 33:183-192. https://doi.org/10.1007/s00468-018-1767-z

Valladares F, Matesanz S, Guilhaumon F et al (2014) The effects of phenotypic plasticity and local adaptation on forecasts of species range shifts under climate change. Ecol Lett 17:1351-1364. https ://doi.org/10.1111/ele.12348

Van der Maaten E, Bouriaud O, van der Maaten-Theunissen M et al (2013) Meteorological forcing of day-to-day stem radius variations of beech is highly synchronic on opposing aspects of a valley. Agric For Meteorol 181:85-93. https://doi.org/10.1016/j. agrformet.2013.07.009

Van der Maaten E, Hamann A, van der Maaten-theunissen M (2017) Species distribution models predict temporal but not spatial variation in forest growth. Ecol Evol 49:2585-2594. https://doi. org/10.1002/ece3.2696

Van Der Maaten E, Pape J, Van Der Maaten-theunissen M et al (2018) Distinct growth phenology but similar daily stem dynamics in three co-occurring broadleaved tree species. Tree Physiol. https ://doi.org/10.1093/treephys/tpy042

Varsamis G, Papageorgiou AC, Merou T et al (2019) Adaptive Diversity of beech seedlings under climate change scenarios. Front Plant Sci 9:1-18. https://doi.org/10.3389/fpls.2018.01918

Vavrčík H, Gryc V, Menšík L, Baar J (2013) Xylem formation in Fagus sylvatica during. Dendrobiology 69:69-75. https://doi. org/10.12657/denbio.069.008

Vilà-Cabrera A, Premoli AC, Jump AS (2019) Refining predictions of population decline at species' rear edges. Glob Chang Biol 25:1549-1560. https://doi.org/10.1111/gcb.14597

Warton DI, Duursma RA, Falster DS, Taskinen S (2012) smatr 3-an $\mathrm{R}$ package for estimation and inference about allometric lines. Methods Ecol Evol 3:257-259. https://doi.org/10.1111/j.2041210X.2011.00153.X

Weigel R, Muffler L, Klisz M et al (2018) Winter matters: Sensitivity to winter climate and cold events increases towards the cold distribution margin of European beech (Fagus sylvatica L.). J Biogeogr. https://doi.org/10.1111/jbi.13444

West-Eberhard MJ (2003) Developmental plasticity and evolution. Oxford University Press, Oxford

Zweifel R (2016) Radial stem variations-a source of tree physiological information not fully exploited yet. Plant Cell Environ 39:231-232. https://doi.org/10.1111/pce.12613

Publisher's Note Springer Nature remains neutral with regard to jurisdictional claims in published maps and institutional affiliations. 